\title{
Cellular and Molecular Characterization of a Brain-enriched Protein Tyrosine Phosphatase
}

\author{
L. M. Boulanger,, ${ }^{1, a}$ P. J. Lombroso, ${ }^{2}$ A. Raghunathan, ${ }^{1}$ M. J. During, ${ }^{3}$ P. Wahle, ${ }^{4}$ and J. R. Naegele ${ }^{1,2}$ \\ ${ }^{1}$ Program in Neuroscience and Behavior, Department of Biology, Wesleyan University, Middletown, Connecticut \\ 06459, ${ }^{2}$ Child Study Center and ${ }^{3}$ Departments of Surgery and Medicine, Yale University School of Medicine, New \\ Haven, Connecticut 06520, and ${ }^{4}$ Lehrstuhl fur Allg. Zoologie und Neurobiologie, Ruhr-Universitat, 44780, Bochum, \\ Germany
}

Regional variations in the expression of a striatal enriched protein tyrosine phosphatase called STEP were studied in the adult rat brain by a combination of immunocytochemistry, lesion studies, Western blotting, and in s/tu hybrldization. Monoclonal antibodies generated against STEP identified multiple polypeptides of $M_{r}, 46,37,33$ and a doublet of $M, 64-66 \mathrm{kDa}$ on Western blots. Although the three STEP immunoreactive bands with lower molecular weights were enriched in cytosolic fractions, the 64-66 kDa doublet was enriched in membrane fractions. All of the immunoreactive forms were abundant in the caudate-putamen and were present in lower amounts or were undetectable in other brain regions. In substantia nigra, the $M_{r}$ 64-66 kDa doublet was not detected but bands with $M_{r}$ 46, 37, and $33 \mathrm{kDa}$ were present. Immunocytochemical and lesion experiments demonstrated that the cytosolic STEP isoforms present in the substantia nigra are in presynaptic axons originating from the projection neurons of the caudate putamen, which innervate this structure. Additional in situ hybridization studies showed that STEP mRNA expression patterns correlate with the patterns of immunocytochemical staining. These findings indicate that there are multiple polypeptide isoforms of STEP enriched in the basal ganglia and related structures which differ in terms of their intracellular locations and functional roles.

[Key words: intracellular PTP, basal ganglia, cerebral cortex, hippocampus, in situ hybridization, immunocytochemical localization]

Protein phosphorylation is a common biochemical pathway enabling extracellular signals to modulate intracellular responses (see reviews by Hunter and Cooper, 1985; Greengard, 1987; Huganir and Greengard, 1990; Ullrich and Schlessinger, 1990; Wallas and Greengard, 1991). A variety of neuronal proteins are

Received Mar. 28, 1994; revised Aug. 8, 1994; accepted Aug. 24, 1994.

The technical assistance of Erika Lukacsi and Feisha Zhao is gratefully acknowledged. J.R.N. thanks Allan Berlind, Madhvi Upender, and Judy Dunn for helpful comments on the manuscript and Gina Appicelli, Peter Kimm, and Jonathan Smith for their contributions. This work was supported by MHPO1 49351 , EY09749 (J.R.N.), NATO Collaborative Grant \#920780 (J.R.N. and P.W.), MH00856, and NARSAD (P.J.L.), and NS06208 and NS28227 (M.J.D.).

Correspondence should be addressed to Dr. Janice R. Naegele, Department of Biology, Hall-Atwater Laboratory, Wesleyan University, 237 Church Street, Middletown, CT 06459-0170.

a Present address: Columbia University, Department of Biological Sciences, Sherman Fairchild Center for the Life Sciences, New York, NY 10027.

Copyright (C) 1995 Society for Neuroscience $0270-6474 / 95 / 151532-13 \$ 05.00 / 0$ regulated by phosphorylation including neurotransmitter and growth factor receptors, cytoskeletal proteins, ion channels, synaptic vesicle proteins, and transcription factors. For the majority of these, phosphorylation occurs frequently on serine and threonine residues and rarely on tyrosine residues. In recent years, however, the number of molecules implicated in the control of tyrosine phosphorylation has increased dramatically (Fisher et al., 1991; Charbonneau and Tonks, 1992).

The two major classes of enzymes that regulate levels of tyrosine phosphorylation are the protein tyrosine kinases and the protein tyrosine phosphatases. Members of these two classes have either transmembrane receptor-like or intracellular forms. The receptor-like protein tyrosine kinases (PTKs) include nerve growth factor receptor (TrkA), insulin- and insulin-like growth factor reccptors, cpidcrmal growth factor receptor, and brain dcrived growth factor receptor. Many of these receptors show developmentally regulated patterns of expression in the brain, suggesting a role in the establishment or maintenance of neural pathways (Klein et al., 1989, 1990; Martin-Zanca et al., 1990).

The protein tyrosine phosphatases (PTPs) are subdivided on the basis of their structural organization (Charbonneau et al., 1989; Fisher et al., 1991; Charbonneau and Tonks, 1992). All known PTPs contain a highly conserved 12 amino acid catalytic domain and are further distinguished on the basis of additional structural motifs. The receptor-like PTPs exhibit an extracellular domain, a single transmembrane and one or two intracellular phosphatase domains (Streuli et al., 1988; Jirik et al., 1990; Kaplan et al., 1990; Matthews et al., 1990; Sap et al., 1990; Tian et al., 1991; Yang et al., 1991; Levy et al., 1993; Sahin and Hockfield, 1993; Walton et al., 1993). The nonreceptor cytoplasmic PTPs contain a single phosphatase domain and additional amino acid sequences that are homologous to motifs found in other classes of proteins. In some instances, these domains are thought to target the PTP to a distinct intracellular compartment. For example, PTP1B and T-cell PTPs are attached to cellular membranes through a regulatory hydrophobic amino segment at their C-terminus (Cool et al., 1989, 1990; Frangioni et al., 1992). Two other tyrosine phosphatases, MEG2 and PTPH1, contain domains which are thought to target them to the cytoskeleton $(\mathrm{Gu}$ et al., 1991; Yang and Tonks, 1991). In other instances, the motifs are thought to determine substrate specificity. For example, several intracellular PTPs contain src homology 2 domains (SH2). These domains bind to phosphotyrosine residues of target proteins. When found on PTPs, they have been postulated to allow for the dephosphorylation of tyrosine residues by bringing 
them into close association with the catalytic domain of the PTP (Shen et al., 1991; Feng et al., 1993; Vogel et al., 1993).

Both receptor-like and nonreceptor PTPs have been identified that exhibit restricted patterns of expression in the adult and developing nervous system (Guan et al., 1990; Lai and Lemke, 1991; I ombroso et al., 1991; Tian et al., 1991; Yang et al., 1991; Levy et al., 1993; Sahin and Hockfield, 1993; Walton et al., 1993). Most of these also undergo developmental regulation. Two PTPs with highly restricted patterns of expression include DPTP99A and DPTP10D. These receptor-like PTPs are expressed by a subset of pioneering axons in the embryonic Drosophila CNS (Tian et al., 1991; Yang et al., 1991). NE-3 is another receptor-like PTP that is first expressed in the rat olfactory neuroepithelium during neurogenesis and is later found at lower levels in the pyramidal cells of the hippocampus, thalamus, cerebral cortex, and cerebellum (Walton et al., 1993). Several other cerebral cortex-enriched PTPs (CPTPs) of both the receptor-like and nonreceptor classes are expressed at highest levels in embryonic and neonatal rat cortical neurons but then are down regulated during maturation (Sahin and Hockfield, 1993).

In previous studies, we cloned and partially characterized a nonreceptor PTP, called STEP, which has a highly restricted pattern of expression in the adult rat brain (Lombroso et al., 1991, 1993). Polyclonal antisera against STEP detected three brainspecific STEP immunoreactive polypeptides in cytosolic fractions which were hypothesized to be functionally related forms of STEP (Lombroso et al., 1993). To test this hypothesis, we generated monoclonal antibodies (mAbs) against a portion of the STEP molecule located outside of the catalytic domain. The resulting STEP mAbs detected the triplet of cytosolic STEP polypeptides previously described, but in addition, a novel higher molecular weight doublet enriched in particulate fractions. The goal of the present study was to investigate regional differences in the expression of different STEP immunoreactive polypeptides by means of Western blotting in combination with immunocytochemical and in situ hybridization analyses. These results have appeared previously in abstract form (Boulanger et al., 1993).

\section{Materials and Methods}

Production of monoclonal antibodies. Monoclonal antibodies to STEP were produced by the method of Kohler and Milstein (1975). BALB/c mice were immunized with $100 \mu \mathrm{g}$ of STEP peptide conjugated to keyhole limpet hemocyanin (KLH) in Freund's complete adjuvant. The peptide consisted of an 18 amino acid sequence towards the $\mathrm{N}$-terminus of STEP which lacked homology to any previously characterized PTP. Mice were hoosted subcutaneously with $40 \mu \mathrm{g}$ of peptide dissolved in $50 \mathrm{~mm}$ sodium bicarbonate ( $\mathrm{pH} 8.0$ ) in Freund's incomplete adjuvant. Splenocytes were removed, dissociated, and fused with mouse myeloma cells (NS1/Ag8) in the presence of polyethylene glycol and plated onto 96 well plates at limiting dilution. Selection for hybrids was accomplished in HAT medium and tissue culture supernatants were screened using ELISA assays against STEP fusion protein (Lombroso et al., 1993). STEP immunoreactive supernatants were rescreened on miniWestern strips and positives were further screened by immunocytochemical staining of rat caudate-putamen. Positive cells were subcloned two additional times, propagated in vitro, and grown as ascites tumors.

Twenty-two mouse monoclonal antibody-producing cell lines were found to secrete supernatants positive in the initial screening process. The mAbs differed in intensity of their immunocytochemical staining in selected brain regions and in their relative affinities for different molecular weight forms of STEP polypeptides on Western blots. Based on combined biochemical and immunocytochemical staining properties, $\mathrm{mAbs} 17 \mathrm{E} 3$ and 23E5 were selected for the studies reported here. Comparisons indicated that both recognized the same polypeptides on West- ern blots but 23E5 gave stronger staining on Western blots and 17E3 produced stronger immunocytochemical staining. Ascites from cell lines $17 \mathrm{E} 3$ and 23E5 were immunoaffinity purified with protein $\mathrm{A}$ (17E3) or protein $\mathrm{G}(23 \mathrm{E} 5)$ and stored at $-80^{\circ} \mathrm{C}$. MAb $23 \mathrm{E} 5$ was used at dilutions of 1:5000 to 1:10,000 and $\mathrm{mAb} 17 \mathrm{E} 3$ was used at dilutions of 1:500 to $1: 2500$. Monoclonal antibodies to tyrosine hydroxylase were purchased commercially (Boehringer Mannheim, dilution 1:200). DARPP-32 antibodies were provided by $G$. Snyder and $P$. Greengard.

Lesions of striatonigral and nigrostriatal neurons. Nigrostriatal projections were eliminated by lesions of the substantia nigra as described by Perese et al. (1989). This protocol results in selective pathology in the A9 cell group, largely sparing the A10 ventral tegmental neurons. Male Sprague-Dawley rats, $280-300$ gm received two separate intranigral injections of $2 \mu \mathrm{l}$ of 6-OHDA $(2 \mu \mathrm{g} / \mu \mathrm{l})$ in $0.9 \%$ saline containing $0.1 \%$ ascorbic acid as an anti-oxidant as described previously (During et al., 1992). To determine the extent of the lesions, animals were tested for rotational behavior in response to apomorphine after a postoperative period of at least $10 \mathrm{~d}$ (Hefti et al., 1980; During et al., 1989). Hefti et al. (1980) demonstrated that animals with contralateral rotation rates greater than $6 / \mathrm{min}$ to systemically administered apomorphine will have greater than $90 \%$ reduction in striatal dopamine content and tyrosine hydroxylase activity. This criterion was used to select animals for STEP, DARPP-32, and tyrosine hydroxylase immunocytochemical staining, 16 months after the lesion.

Striatal lesions were performed to ablate striatonigral projection neurons in two adult male Sprague-Dawley rats (280-300 gm). Each animal received a striatal lesion made by stereotaxic injection of kainic acid as described previously, with modifications (Walaas and Greengard, 1984). One microliter of kainic acid ( $5 \mathrm{~mm}$ ) was injected into the right caudate-putamen over a 4 min interval. The needle was left in place for an additional $3 \mathrm{~min}$ and withdrawn. One month after the lesion, the brains were processed for immunocytochemical staining, as described below.

Western blots. Long-Evans rats $(N=10)$ were euthanized by $\mathrm{CO}_{2}$ inhalation. Brains were immediately removed, dissected, and placed immediately into homogenization buffer (HB) containing $320 \mathrm{~mm}$ sucrose, $1 \mathrm{~mm}$ PMSF, and $1 \mathrm{~mm}$ aprotinin. Dissections from different brain regions included caudate-putamen, hippocampus, substantia nigra, frontal, and occipital cortex. Tissue was homogenized using a Teflon in glass homogenizer and centrifuged for $10 \mathrm{~min}$ at $1000 \times g$ to obtain supernatant (S1) and P1 fractions. S1 was centrifuged at $10,000 \times g$ for 10 min to obtain $\mathrm{S} 2$ and $\mathrm{P} 2$ fractions. For those experiments in which we were interested in looking at cytosol versus membrane fractions, the S2 fraction was centrifuged at $200,000 \times g$ for $1 \mathrm{hr}$ to obtain $\mathrm{S} 3$ (cytosol) and P3 (crude membrane) fractions. For those experiments in which we were interested in also examining synaptosomal fractions (Fig. 1), synaptosomes were lysed by resuspending P2 in $2.5 \mathrm{ml}$ of $320 \mathrm{mM}$ sucrose buffer to which $25 \mathrm{ml}$ of ice cold $\mathrm{H}_{2} \mathrm{O}$ was quickly added and the sample homogenized with three strokes at $2000 \mathrm{rpm}$. HFPFS buffer $(\mathrm{pH} 7.5)$ was added to a final concentration of $10 \mathrm{~mm}$. The sample was centrifuged at $16,500 \mathrm{rpm}$ to obtain a lysed pellet 1 (LP1) and lysed supcrnatant 1 (LS1). LS1 was centrifuged for $2 \mathrm{hr}$ at $100,000 \times g$ to obtain LP2 and LS2. Fractions were assayed for protein concentration by the method of Bradford (1976). Purified synaptic vesicles (CPG fraction) were prepared as described in Huttner et al. (1983) and McPherson et al. (in press) and were kindly provided by Peter McPherson.

The different subcellular fractions were loaded onto $10 \%$ SDS-polyacrylamide gels, separated by electrophoresis, and transferred onto nitrocellulose filters (Laemmli, 1970; Towbin et al., 1979). Blots were stained with Ponceau S (Sigma) to visualize transferred proteins, blocked with $5 \%$ Blotto, and incubated overnight with monoclonal antibodies. Blots were washed extensively before the addition of alkaline phosphatase conjugated goat anti-mouse secondary (Bio-Rad, dilution 1:4000), incubated for $1 \mathrm{hr}$, and processed as previously described (Lombroso et al., 1993).

Controls. To assess specificity of staining on Westem blots or on tissue sections, $1 \mu$ l of STEP monoclonal antibody was diluted 1:500, preabsorbed with $10 \mu \mathrm{g}$ to $20 \mu \mathrm{g}$ of STEP peptide for $18 \mathrm{hr}$, and brought to a final dilution of 1:1000 prior to incubation with tissue sections. In addition, some lanes were incubated with preimmune mouse serum and the blots were processed through secondary antibodies and color development solutions.

Immunocytochemistry. Long Evans and Sprague-Dawley rats (Charles River) were deeply anesthetized with Nembutal $(60 \mathrm{mg} / \mathrm{kg}$, i.p.) and perfused transcardially with $50 \mathrm{ml}$ of $0.1 \mathrm{M}$ phosphate buffered 
saline (PBS) containing $0.1 \mathrm{U} / \mathrm{ml}$ sodium heparin followed by $4 \%$ paraformaldehyde in $0.1 \mathrm{M}$ PBS, $\mathrm{pH}$ 7.4. Brains were removed, blocked, cryoprotected, embedded in Polyfreeze (Polysciences) and $12 \mu \mathrm{m}$ thick sections were placed onto polylysine coated glass slides. Cryostat sections were stored at $-80^{\circ} \mathrm{C}$. Alternatively, $40 \mu \mathrm{m}$ thick sections were cut and stored free-floating in $50 \mathrm{~mm}$ Tris buffered saline (TBS) and glycerol $(1: 1)$ at $-20^{\circ} \mathrm{C}$ until staining was performed.

Sections were incubated in $0.1 \mathrm{M}$ PBS containing $5 \%$ normal serum and $0.5 \%$ Triton $\mathrm{X}-100$ for $1 \mathrm{hr}$ and processed for immunoperoxidase cytochemistry, according to Lombroso et al. (1993), except that mouse mAbs 17E3 or 23E5 were diluted in $0.1 \mathrm{M}$ PBS containing 5\% normal horse serum. Detection was accomplished with an avidin-biotin-peroxidase system (Vector Labs; Lombroso et al., 1993). For lesion studies, DARPP-32 and tyrosine hydroxylase were used in addition to STEP mAbs at dilutions as described above.

Digoxigenin in situ hybridization. In situ hybridization studies employed digoxigenin-labeled cRNA probes and were performed following the protocol of Wahle and Beckh (1992), with modifications as described below. Digoxigenin-labeled cRNA probes for STEP mRNA were synthesized from a $2.4 \mathrm{~kb}$ STEP cDNA and stored at $-20^{\circ} \mathrm{C}$ until use (Wahle and Beckh, 1992).

Perfusion, hybridization, and detection. Sprague-Dawley rats $(N=$ 4) were anesthetized with Nembutal (60 mg/kg, i.p.) and perfused transcardially with $200 \mathrm{ml}$ of $4 \%$ paraformaldehyde in $0.1 \mathrm{M}$ PBS. The brains were removed, blocked, cryoprotected, and frozen rapidly on dry ice. Forty micrometer thick cryostat sections were thawed into $0.3 \mathrm{M}$ sodium chloride containing $30 \mathrm{~mm}$ sodium citrate, $\mathrm{pH} 7.4(2 \times \mathrm{SSC})$ and processed free-floating. Permeabilization was performed for $10 \mathrm{~min}$ in $10 \mathrm{~mm}$ Tris containing $5 \mathrm{~mm}$ EDTA and $1 \mu \mathrm{g} / \mathrm{ml}$ proteinase $\mathrm{K}$, and then sections were rinsed for $15 \mathrm{~min}$ in $2 \times \mathrm{SSC} / 2 \mathrm{mM}$ EDTA, and equilibrated for $5 \mathrm{~min}$ in $2 \times \mathrm{SSC} / 50 \%$ prehybridization mix.

STEP CRNA sense and antisense probes were diluted 1:100 to 1:300 in prehybridization buffer and applied to tissue sections overnight at $45^{\circ} \mathrm{C}$. Control sections were incubated in the same buffer without sense or antisense cRNA. Digoxigenin labeled probes were detected by incubation in Fab portions of alkaline phosphatase conjugated anti-digoxigenin antibody (Boehringer Mannheim, 1:1500) followed by several rinses and incubation in alkaline phosphatase color substrates BCIP and NBT. Sections were mounted onto polylysine-coated slides, air dried, and coverslipped in water-based compound (Airvol, Air Products).

\section{Results}

STEP monoclonal antibodies recognize four STEP immunoreactive polypeptides in the brain

Previous studies with a rabbit antiserum specific for STEP identified a major cytosolic band of $46 \mathrm{kDa}$ in rat whole brain fractions and two additional bands of 37 and $33 \mathrm{kDa}$ in striatal fractions (Lombroso et al., 1993). The mouse monoclonals generated for the present study also reacted strongly with these bands, as shown in Figure 1. Additionally, the mAbs detected a new doublet with a mobility of $64-66 \mathrm{kDa}$, enriched in particulate fractions. The specificity of the staining patterns was demonstrated by preabsorption of the mAbs with STEP peptide or by omission of the mAb from the staining procedure and both conditions abolished immunoreactivity. Western blot comparisons of the rabbit polyclonal and mAbs $17 \mathrm{E} 3$ and 23E5 indicated that although both the polyclonal and monoclonal antibodies recognized the $46 \mathrm{kDa}$ polypeptide, the polyclonal antiserum was significantly less sensitive and did not detect the $65 \mathrm{kDa}$ membrane enriched band (data not shown). The remaining cytosolic bands of 37 and $33 \mathrm{kDa}$ were faintly labeled by the antiserum but strongly detected by the mAbs (not shown). Due to the greater sensitivity of the two monoclonal antibodies, the remainder of the experiments described here were carried out with these reagents.

The STEP immunoreactive bands described above were designated $\mathrm{STEP}_{65}, \mathrm{STEP}_{46}, \mathrm{STEP}_{37}$, and $\mathrm{STEP}_{33}$. Although the STEP $_{65}$ and STEP $_{46}$ bands were detected in whole brain homogenates $(\mathrm{H})$ and in initial subcellular fractions containing nuclei and blood vessels $\left(P_{1}\right)$ or crude membranes $\left(P_{2}\right)$, we found a striking enrichment of $\mathrm{STEP}_{46}, \mathrm{STEP}_{37}$, and $\mathrm{STEP}_{33}$ in the cytosolic fraction $\left(S_{3}\right)$ and selective enrichment of STEP $_{65}$ in the membrane-enriched fractions containing small organelles $\left(P_{3}\right)$ and crude synaptic vesicles $\left(\mathrm{LP}_{2}\right)$ (Huttner et al., 1983) (Fig. 1). The lower molecular weight STEP-immunoreactive bands were depleted, but not completely removed from the membrane-enriched fractions, most likely due to the limited presence of some cytosolic components in the $\mathrm{P}_{3}$ and $\mathrm{LP}_{2}$ fractions.

The enrichment of $\mathrm{STEP}_{46}, \mathrm{STEP}_{37}$, and $\mathrm{STEP}_{33}$ in the S3 fraction corroborates a previous study in which these STEP isoforms were detected in brain homogenate and partitioned into the aqueous phase following Triton $\mathrm{X}-114$ extraction expcriments (Lombroso et al., 1993). Although the increased abundance of STEP 65 in the LP2 fraction suggested a specific association with synaptic vesicles, STEP immunoreactivity was depleted from a purified synaptic vesicle fraction (Fig. 1, lane CPG; synaptic vesicles courtesy of Peter McPherson and Pietro DeCamilli).

\section{STEP polypeptides are differentially enriched in various cortical and subcortical regions}

We next examined whether STEP immunoreactive polypeptides varied in their patterns of expression within different brain regions. When equivalent amounts of protein from the S3 fractions of different regions were probed for STEP immunoreactivity on Western blots, we found that frontal cortex exhibited a greater enrichment in $\mathrm{STEP}_{46}$ (Fig. 2A, lane 1) compared with occipital cortex (Fig. $2 A$, lane 2 ) or hippocampus (Fig. $2 A$, lane 3). STEP $_{37}$ was faintly detected in frontal cortex and hippocampus (Fig. 2A, lane 1) but not in occipital cortex. In contrast, $\mathrm{STEP}_{46}, \mathrm{STEP}_{37}$, and $\mathrm{STEP}_{33}$ were all strongly enriched in S3 fractions prepared from the striatum (Fig. $2 A$, lane 4). When we examined $S 3$ fractions prepared from the substantia nigra, $\mathrm{STEP}_{46}$ and $\mathrm{STEP}_{37}$ were clearly present and $\mathrm{STEP}_{33}$ was faintly detectable (Fig. $2 A$, lanc 5). Prcabsorption of the antibodies with STEP peptide abolished the staining (Fig. $2 C$, lane 1). We present evidence below that this nucleus contains only STEP immunoreactive axons and synaptic terminals and no immunoreactive cell bodies, suggesting that $\mathrm{STEP}_{46}, \mathrm{STEP}_{37}$, and $\mathrm{STEP}_{33}$ are transported from the cell body of striatal neurons to their axonal endings in the substantia nigra (see Fig. 3).

We compared regional variations in $\mathrm{STEP}_{65}$ in different cortical and subcortical regions, and the results are shown in Figure $2 B$. When equivalent amounts of protein from P3 fractions from different brain regions were compared for levels of $\mathrm{STEP}_{65}$, we found that nearly equivalent levels were present in frontal cortex (Fig. 2B, lane 1), occipital cortex (Fig. 2B, lane 2), and hippocampus (Fig. $2 B$, lane 3). By contrast, a slight increase in levels of STEP ${ }_{65}$ was found in striatum P3 fractions (Fig. 2B, lane 4) whereas $\mathrm{STEP}_{65}$ was not detectable in P3 fractions of the substantia nigra (Fig. 2B, lane 5). The staining was abolished by preabsorption with STEP peptide (Fig. 2C, lane 2).

\section{STEP immunoreactivity is present in the projection neurons of the striatum and their axons}

To further compare regional variations in STEP, immunostaining was performed on tissue sections. STEP immunoreactivity was cvident within a majority of striatal neuron cell bodies and dendrites (Fig. 3A). In addition, there were immunoreactive axons of striatal neurons which were observed to descend into the globus pallidus (Fig. 3D). Additional immunoreactive axons de- 


\section{MW}

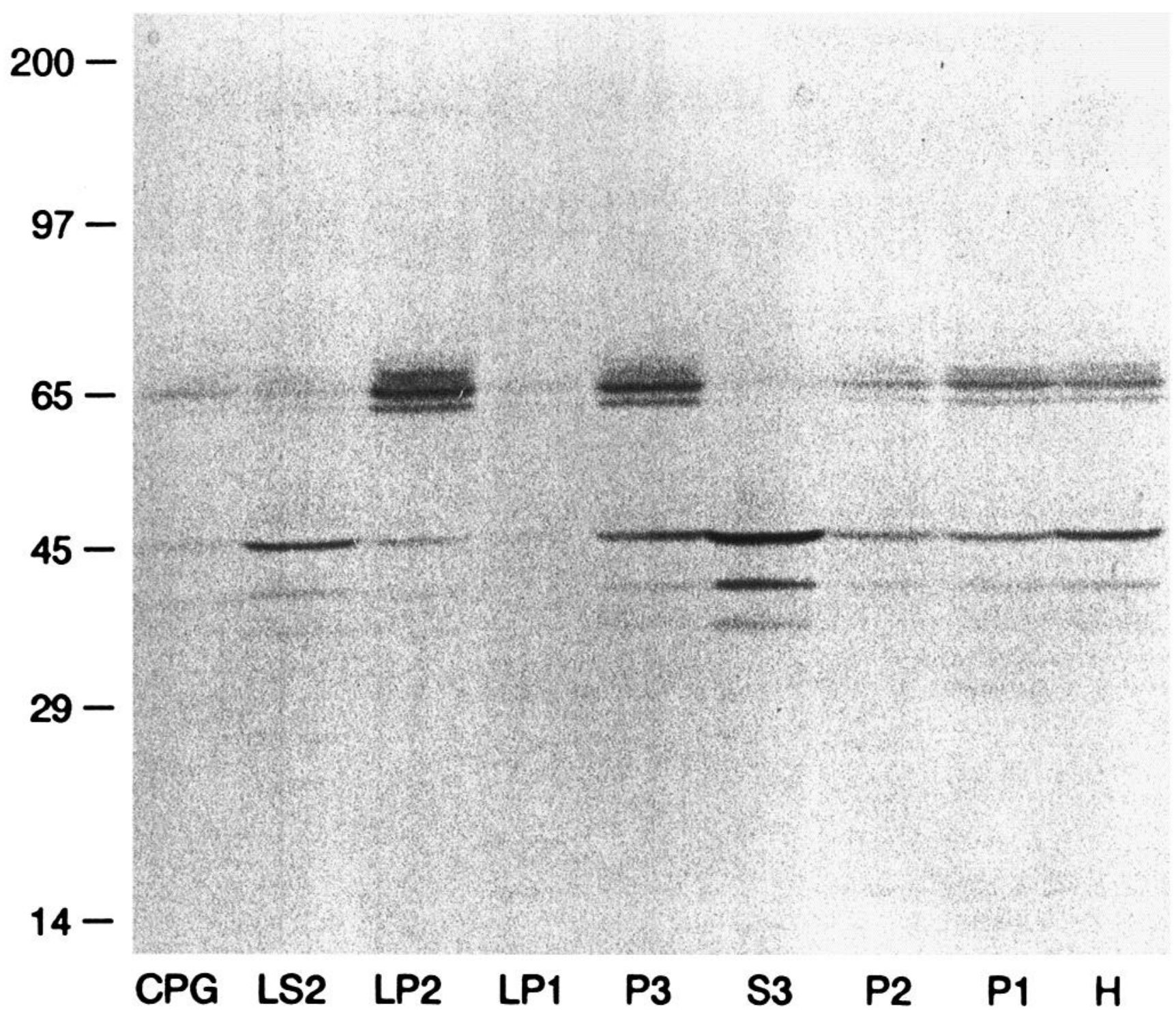

Figure 1. Western blot of subcellular fractions of whole adult brain. $\mathrm{STEP}_{46}, \mathrm{STEP}_{37}$, and $\mathrm{STEP}_{33}$ are enriched in cytosol fractions (lane $S_{3}$ ). $\mathrm{STEP}_{65}$ is enriched in particulate fractions (lanes $P 3$ and $L P 2$ ). Molecular weight of standard proteins shown on left. Abbreviations: $H$, whole brain homogenate; $P 1$, nuclei, unbroken cells, and blood vessels; $P 2$, crude membranes; $S 3$, cytosol; $P 3$, small organelles; $L P I$, lysed synaptosomal membranes and mitochondria; $L P 2$, synaptic vesicles and small organelles; $L S 2$, synaptic vesicle supernatant; $C P G$ (controlled-pore glass beads), purified synaptic vesicles. One hundred micrograms of protein/lane, 7-20\% gradient gel.

scended toward and into the substantia nigra, pars reticulata (Fig. $3 B$ ), and the entopeduncular nucleus (Fig. $3 C$ ). By contrast, STEP immunoreactive cell body staining was absent in these three target nuclei of the striatum.

STEP immunoreactive axons present in the substantia nigra and entopeduncular nuclei could not be followed directly back to immunoreactive cell bodies in the striatum. Hence, we conducted lesion experiments to determine whether these axonal populations originated from striatal projection neurons. Kainic acid lesions of the caudate-putamen or 6-hydroxydopamine (6-OHDA) lesions of the substantia nigra were performed. The efficiency of the lesions was assessed with behavioral measurements as well as by immunocytochemistry with antibodies against tyrosine hydroxylase, dopamine- and cAMP-regulated phosphoprotein-32 (DARPP-32) and STEP. Tyrosine hydroxylase staining was examined to determine the extent of dopamine containing cell bodies and axons, since this enzyme is rate-limiting in the synthesis of dopamine. The DARPP-32 phosphoprotein has been found previously to be enriched in dopaminoceptive neurons and is particularly abundant in striatal projection neurons (Hemmings et al., 1984; Ouimet et al., 1984). Since DARPP-32 colocalizes with STEP in striatal neurons, this marker also served as a positive control for any reductions found in STEP (Lombroso et al., 1993). Striatal lesions produced by injection of kainic acid resulted in a loss of neurons intrinsic to the caudate-putamen and as a consequence, both STEP and DARPP-32 immunoreactivity in the caudate-putamen were depleted (Fig. 4A,B; see Walaas et al., 1984, for similar results using DARPP-32). 


\section{A \\ B}
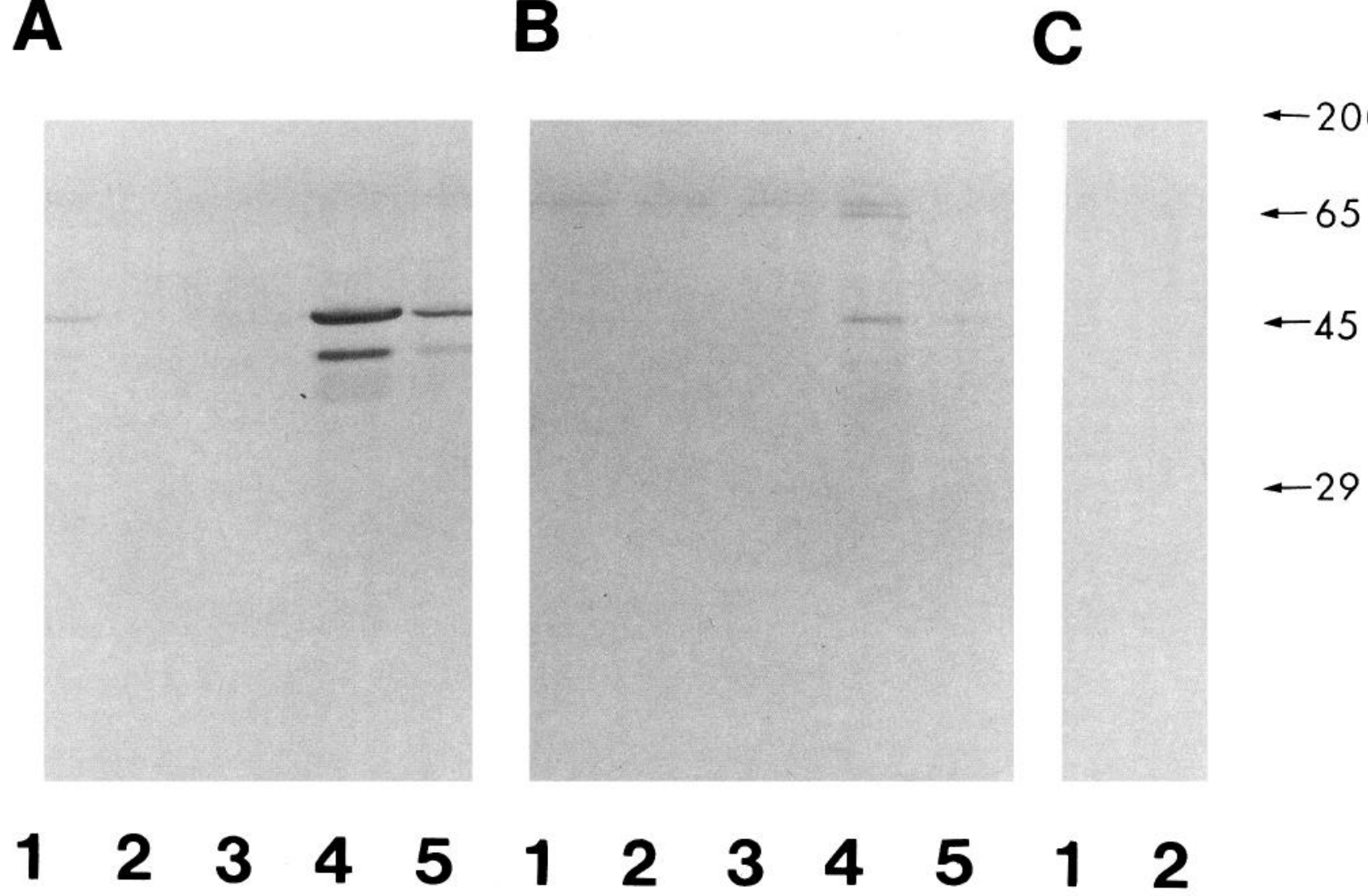

Figure 2. Western blots of different brain regions showing STEP immunoreactive bands in cytosolic and membrane fractions. A, S3 (cytosol) fractions; $B$, P3 (membrane) fractions. For both $A$ and $B$ : lane 1, frontal cortex; lane 2, occipital cortex; lane 3, hippocampus; lane 4, striatum; lane 5, substantia nigra. Specific staining was abolished by preincubation of STEP antibodies with STEP peptide as shown in blot $C$, lane 1 (striatum cytosol), lane 2 (striatum membrane fractions); $100 \mu \mathrm{g}$ protein/lane, $10 \%$ acrylamide gels.

6-OHDA lesions of the substantia nigra resulted in degeneration of dopaminergic neurons in the substantia nigra and depletion of dopaminergic afferents to the caudate-putamen, as shown by a striking reduction in tyrosine hydroxylase immunoreactive cell bodies in the substantia nigra and a loss of tyrosine hydroxylase immunoreactive axons innervating the caudate-putamen (Fig. 4F; see also During et al., 1992).

Kainic acid injections in the rostral caudate reduced STEP (Fig. $4 A$ ) and DARPP-32 immunoreactive fibers in the ipsilateral substantia nigra (Fig. $4 B$ ) but did not affect tyrosine hydroxylase immunoreactivity in neuronal cell bodies of the substantia nigra (Fig. $4 C$ ). By contrast, 6-OHDA lesions of the substantia nigra destroyed nigral dopaminergic neurons and fibers and abolished nigral tyrosine hydroxylase staining (Fig. $4 F$ ) but did not affect levels of STEP (Fig. $4 D$ ) or DARPP-32 (Fig. $4 E$ ) immunoreactivity in the caudate-putamen. Several cases in which surgical hemisections were made to induce degeneration of both the nigrostriatal and striatonigral fiber tracts resulted in reduced STEP and DARPP-32 staining in the substantia nigra, and reduced TH staining in the caudate-putamen (data not shown). In summary, the presence of STEP immunoreactivity in afferent axons but not within intrinsic cell bodies of striatal target nuclei and the abolition of this staining following direct striatal lesions or transection of striatal efferent pathways, demonstrated that striatal neurons supply the STEP immunoreactive axons observed in the substantia nigra. These findings are consistent with the fact that the density of STEP immunoreactive axons in the other major terminal zones of the caudate-putamen were also diminished after striatal lesions.

\section{Cellular localization of STEP in other brain areas}

We examined the extent and localization of STEP in some of the other brain regions exhibiting STEP immunoreactive bands on - Western blots. In the forebrain structures, the most striking staining was in cerebral cortex and hippocampus. In the frontal cortex, pyramidal cell bodies and proximal dendrites in layers $2+3,5$, and 6 were strongly STEP immunoreactive, with layer 5 and upper layer 2 containing the strongest staining (Fig. $5 A$ ). Some cortical areas, such as the piriform cortex, exhibited enhanced immunoreactive staining in comparison to other sensory or motor areas of cerebral cortex (Fig. 5B). In the hippocampus, pyramidal cells in region CA2 were more intensely labeled than the pyramidal cell bodies in areas CA1 and CA3 (Fig. $5 C, D$ ) and other cell populations of the hippocampus were nonimmunoreactive.

A number of subcortical areas also exhibited prominent STEP immunoreactivity. These included the lateral septal nucleus (Fig. $5 E$; see also Lombroso et al., 1993) and the dorsal medial nucleus of the hypothalamus (Fig. $5 F, G$ ). Both of these neuronal populations exhibited intense somatic and dendritic labeling.

Other areas of the thalamus, midbrain and brainstem exhibited weaker, but detectable STEP immunostaining in cell bodies or axons. Camera lucida tracings in Figure 6 summarize these and other labeled areas with axonal (left half of brain sections) or cell body labeling (right of sections). A detailed list of STEP 

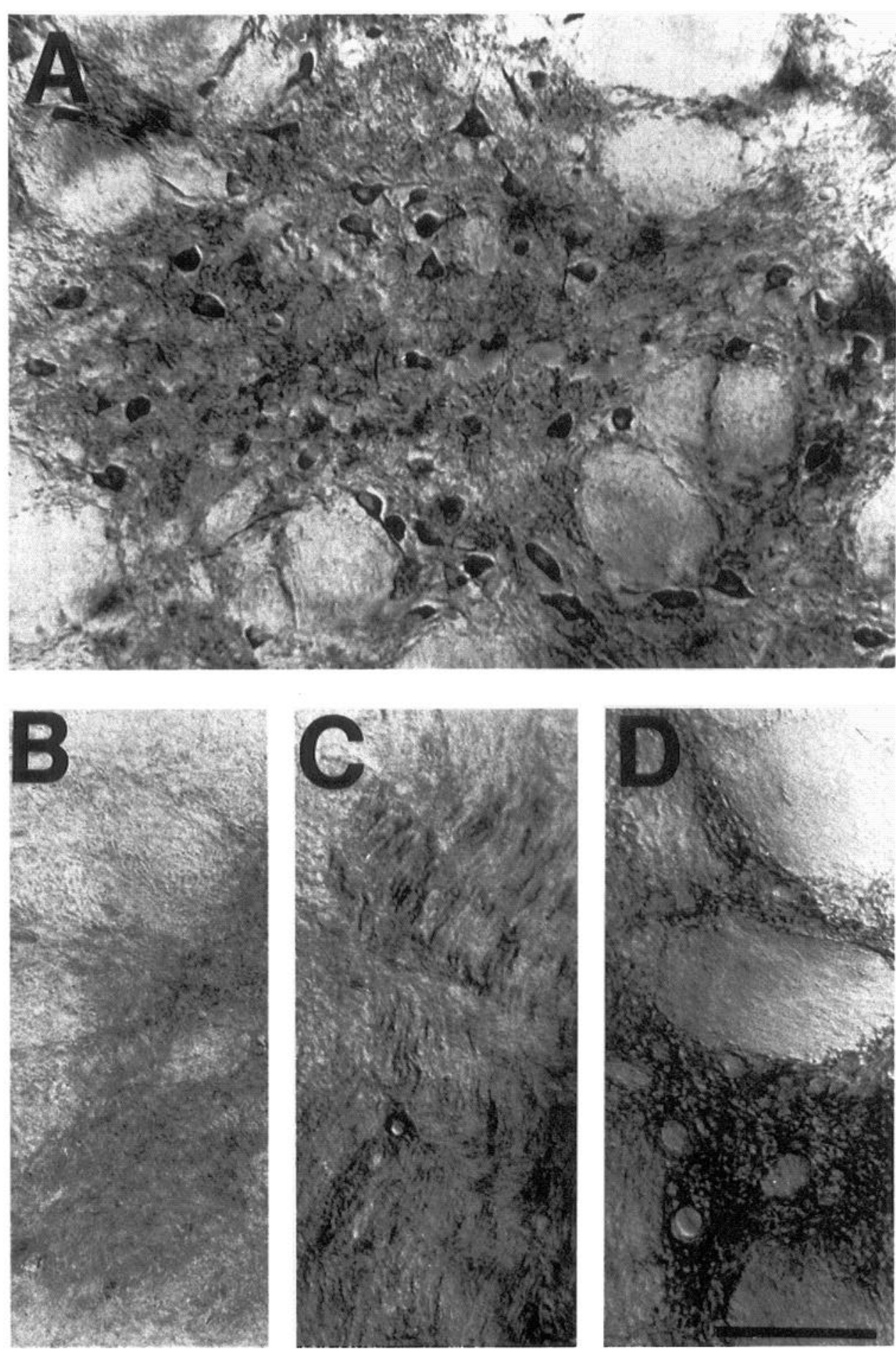

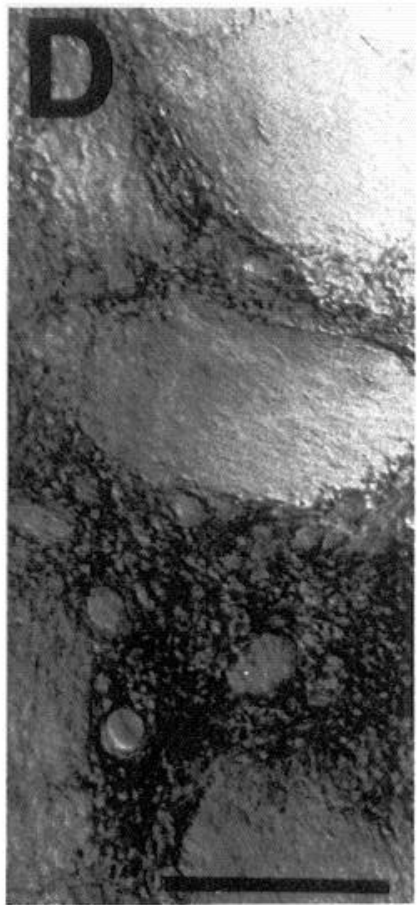

Figure 3. Photomicrographs of STEP immunoreactivity in the caudate-putamen and its efferent targets. $A$, Coronal sections through the caudate-putamen showing STEP immunoreactive cell bodies and neuropil. STEP immunoreactive axons but not cells are present in striatal target nuclei; $B$, substantia nigra pars reticulata; $C$, entopeduncular nucleus; and $D$, globus pallidus. Scale bar, $30 \mu \mathrm{m}$. immunoreactive structures throughout the brain is given in Table 1 .

STEP $m$ RNA expression overlaps with the distribution of STEP immunoreactive polypeptides shown by Western analyses and by immunocytochemistry

To determine whether brain regions containing high levels of STEP immunoreactivity correlated with levels of STEP message, in situ hybridization was performed with digoxigenin labeled cRNA probes. Hybridization signals were most intense in caudate-putamen (Fig. 7A), cortical areas, including piriform cortex
(Fig. $7 B$ ), layers $2+3,5$, and 6 of frontal cortex (Fig. 7C) and pyramidal cells of the hippocampus (Fig. 7D). STEP mRNA was not detected in areas containing only STEP immunoreactive fibers such as the substantia nigra, pars reticulata, entopeduncular nucleus, and the pontine nucleus. Signals were absent from regions which lacked immunostaining and from white matter fiber tracts (Fig. 7D), indicating no significant mRNA in glia.

\section{Discussion}

Previously, a cDNA was isolated and determined to encode for a protein with a predicted molecular weight of $42 \mathrm{kDa}$ (Lom- 


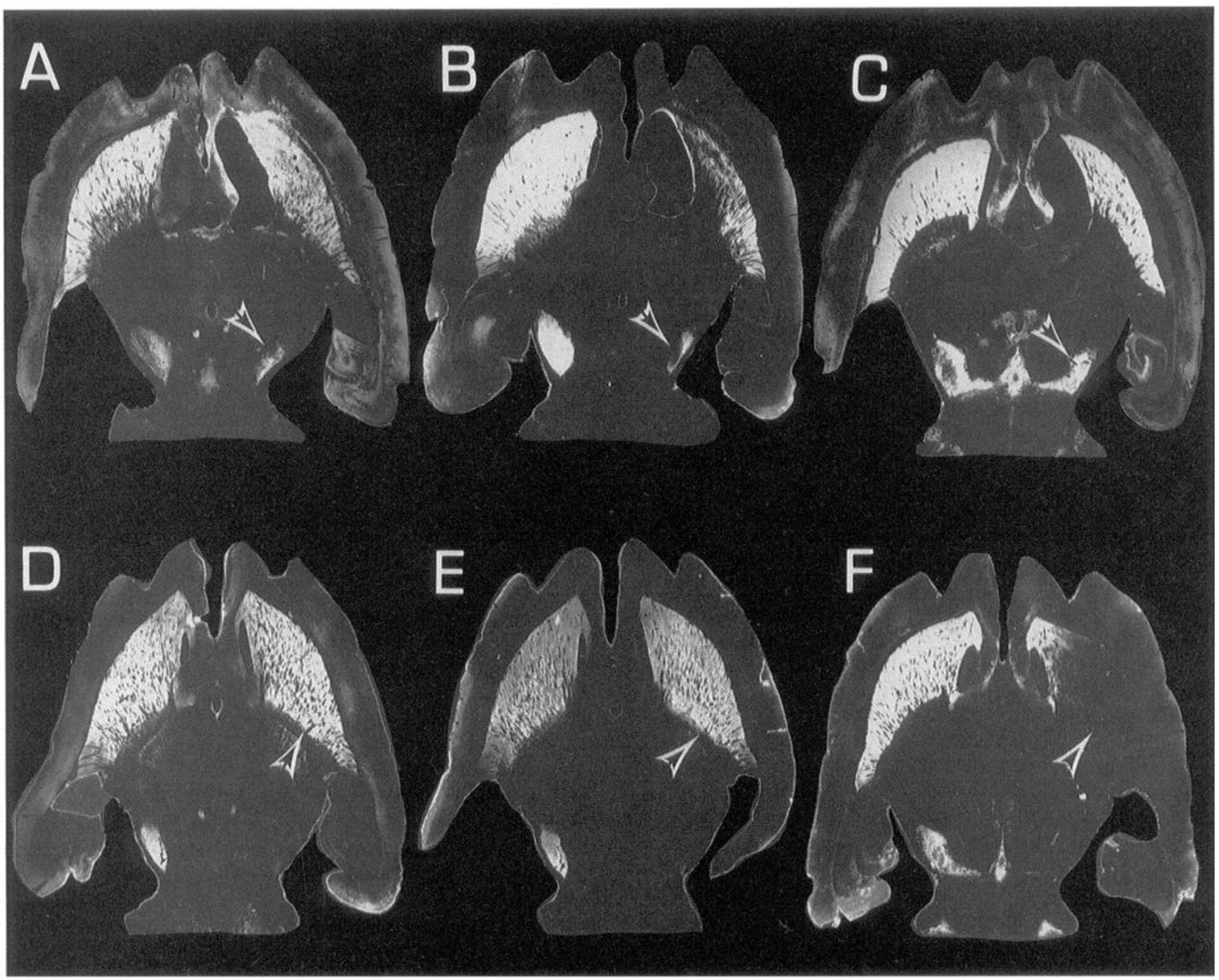

Figure 4. STEP, DARPP-32, and tyrosine hydroxylase immunoreactivity following lesions of caudate-putamen or substantia nigra. $A-C$, Caudateputamen lesions. $D-F$, Substantia nigra lesions. Following striatal lesions, both STEP $(A)$ and DARPP-32 $(B)$ immunoreactive axons are lost in the ipsilateral substantia nigra (arrows). This lesion does not alter tyrosine hydroxylase immunoreactivity in the substantia nigra $(C)$. In contrast, nigral lesions fail to alter STEP $(D)$ or DARPP-32 $(E)$ immunoreactivity in the ipsilateral striatum but result in a marked loss of tyrosine hydroxylase immunoreactivity in the striatum $(F$, arrows $)$. Rostral is at the top.

broso et al., 1991). A subsequent study showed that three STEP immunoreactive bands were present in the striatum (Lombroso et al., 1993). A major finding of the present study is that there are additional STEP immunoreactive bands that vary in their relative enrichment in different brain regions and subcellular fractions.

In our previous study describing STEP immunoreactive proteins, a polyclonal antisera was utilized which was generated by immunizing rabbits with the same 18 amino acid peptide utilized in the present study for monoclonal antibody production (Lombroso et al., 1993). With the polyclonal antisera, dilutions of $1: 25$ to $1: 50$ were required to detect $\mathrm{STEP}_{46}, \mathrm{STEP}_{37}$, and STEP $_{33}$. Despite the low dilutions, the higher molecular weight form of $\mathrm{STEP}_{65}$ was not detected. In addition, we previously utilized a procedure for preparing brain homogenates which did not involve the preparation of cytosolic and membrane fractions which were shown in our present study to enrich for the different STEP isoforms selectively. It seems likely that the failure to detect STEP $_{65}$ in our previous study was due to a combination of factors including the lower titer of the antiserum as compared with the monoclonal antibodies and methodological differences in the preparation of subcellular fractions for biochemical analyses.

\section{Differences in the relative abundance of STEP polypeptide} forms may correspond to differences in their functional roles

The triplet of $\mathrm{STEP}_{46}, \mathrm{STEP}_{37}$, and $\mathrm{STEP}_{33}$ was selectively enriched in cytosolic fractions and expressed at highest levels in the caudate-putamen. Of these, $\mathrm{STEP}_{46}$ was the isoform also most abundantly expressed within cortical and subcortical regions. Further differences in the relative abundance of these isoforms were found in different cortical areas. Combined immunocytochemistry and lesion experiments showed that $\mathrm{STEP}_{46}$,

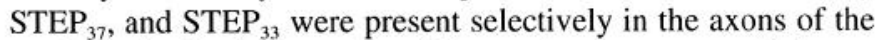
medium-sized spiny neurons of the caudate-putamen which project to the substantia nigra, pars reticulata. The substantia nigra 

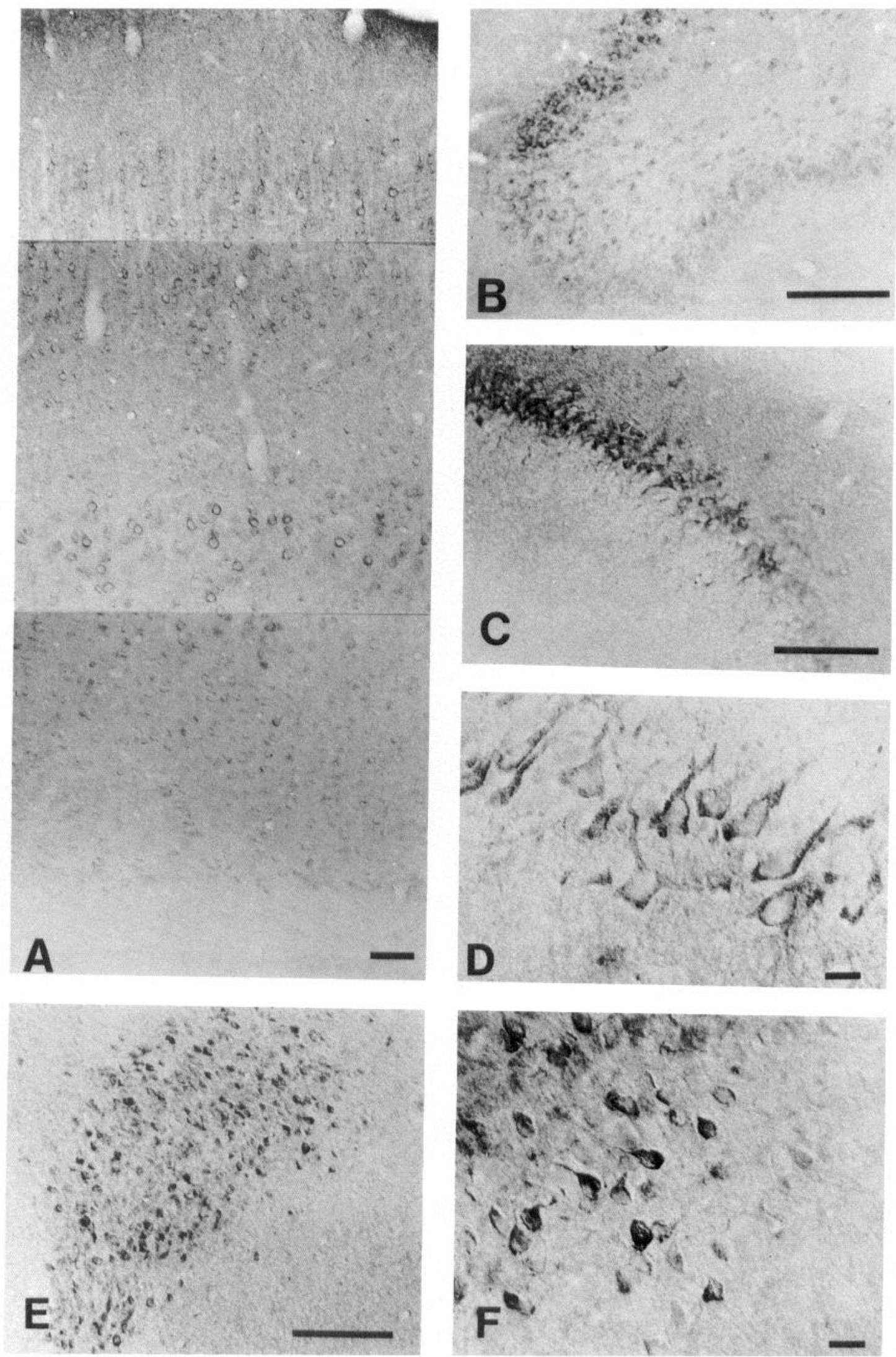

Figure 5. Photomicrographs showing STEP immunoreactivity in cortical and subcortical brain regions. A, STEP immunoreactive pyramidal neurons are visible in cortical layers II+III, V, and VI in occipital cortex; $B$, piriform cortex; $C$, hippocampus, low power view; $D$, hippocampal pyramidal cell layer, high magnification view; $E$, dorsomedial hypothalamic nucleus, low power view; $F$, dorsomedial hypothalamic nucleus, high power view. Scale bars: $A-C$ and $E, 100 \mu \mathrm{m} ; D$ and $F, 10 \mu \mathrm{m}$. 
A
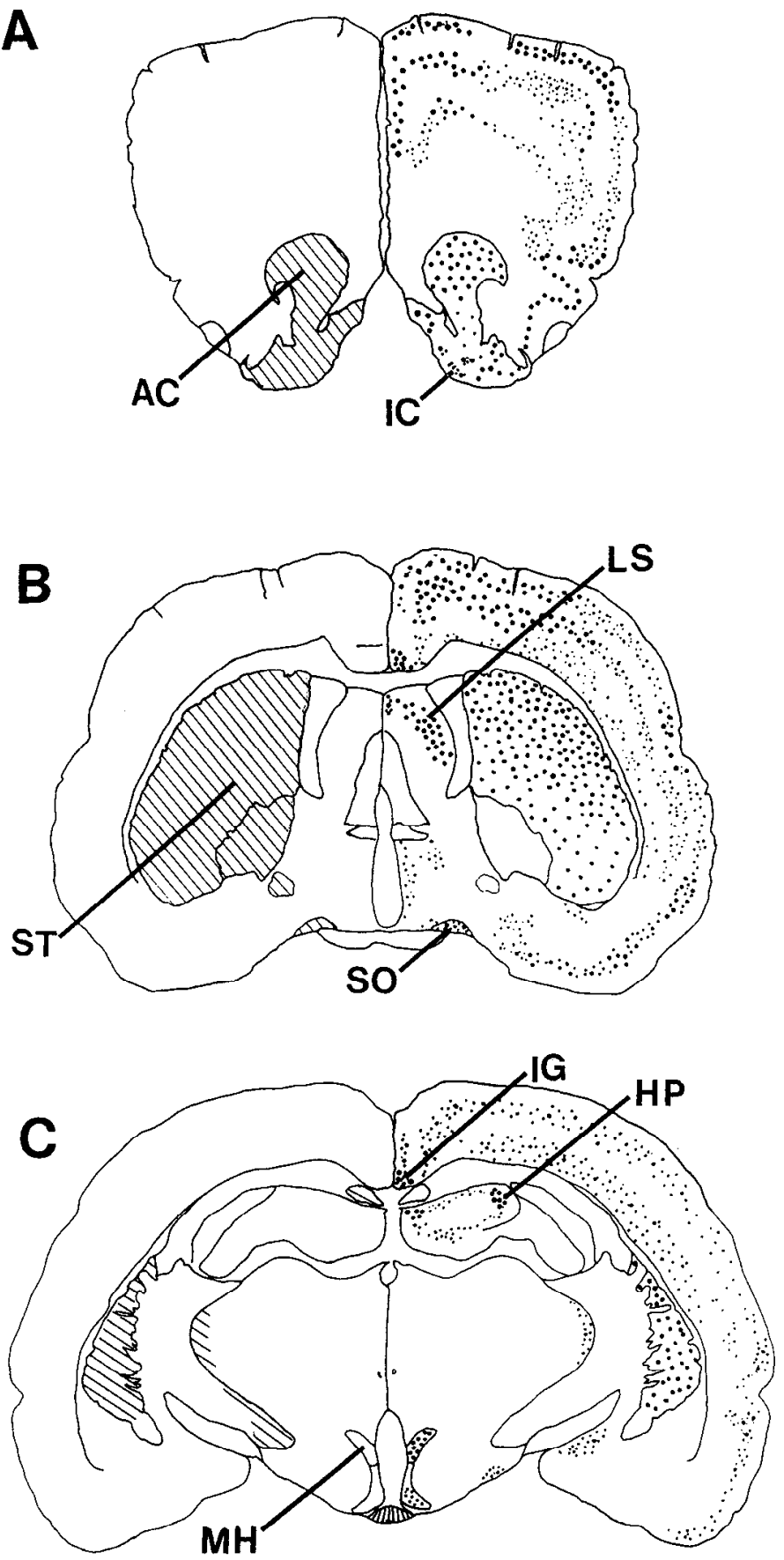
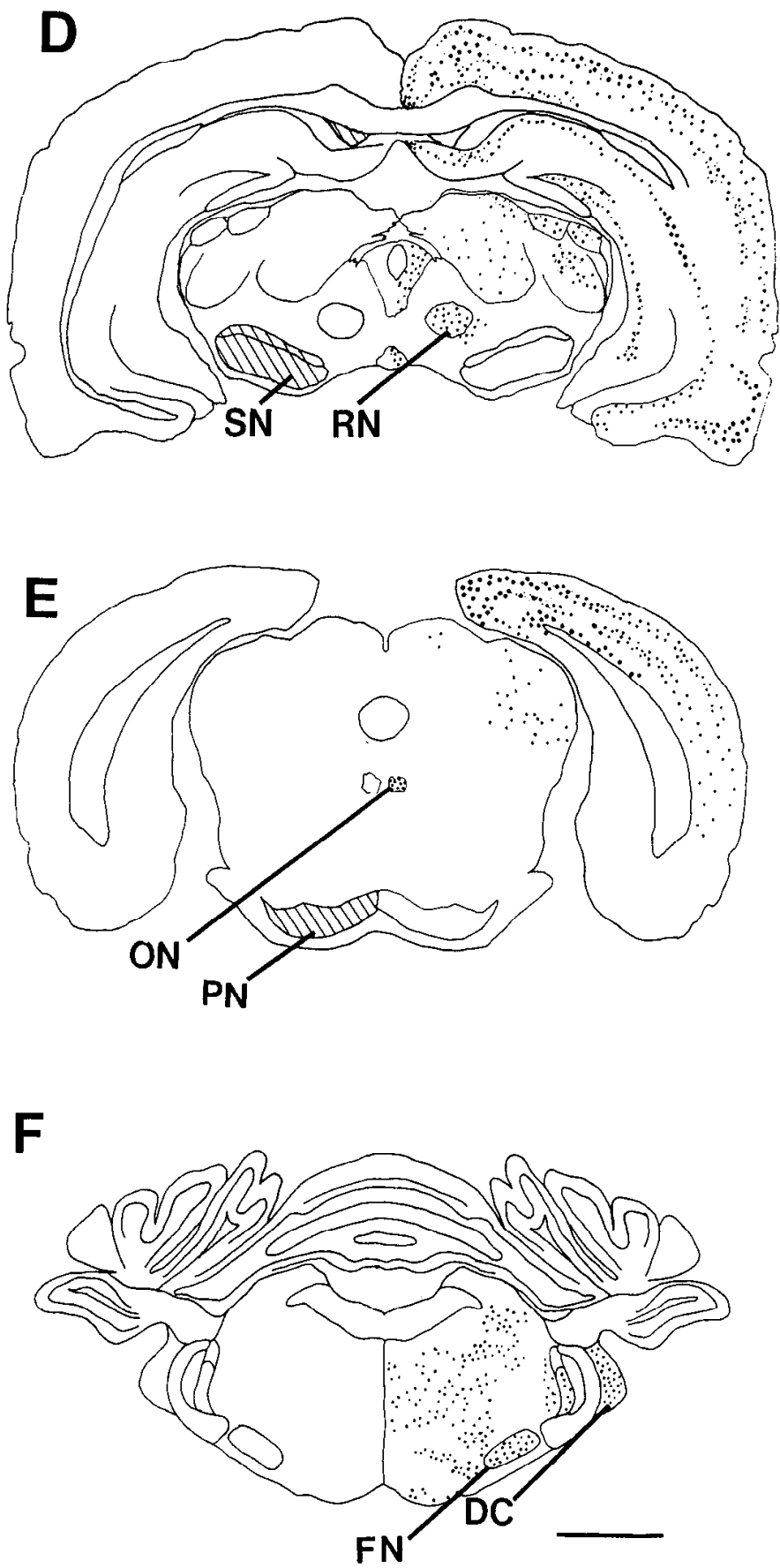

Figure 6. Camera lucida tracings of coronal sections through adult rat brain showing STEP immunostaining with mAb 23E5. Only strongly immunoreactive regions are represented. $A-F$ are ordered rostral to caudal. Immunoreactive somata represented as dots on right of tracings and immunoreactive axons are represented as cross-hatching on left side of sections. Dot density corresponds to density of immunoreactive somata and dot size corresponds to staining intensity. Abbreviations: $A C$, accumbens nucleus; $D C$, dorsal cochlear nucleus; IC, islands of Calleja; $S T$, corpus striatum; $S O$, supraoptic nucleus; $L S$, lateral septal nucleus (intermediate); $M H$, dorsomedial hypothalamic nucleus; $I G$, indusium griseum; $H P$, hippocampus; $S N$, substantia nigra; $R N$, red nucleus; $O N$, oculomotor nucleus; $P N$, pontine nucleus; $F N$, facial nucleus. Scale bar, 2 mm.

lacked STEP immunoreactive cell bodies and further biochemical studies will be necessary to determine whether STEP $_{46}$, STEP $_{37}$, and STEP $\mathrm{S}_{33}$ are also found within other targets of striatal projection neurons.

A major new finding of the present study was that $\mathrm{STEP}_{65}$ alone was further enriched in the particulate fractions P3 and LP2. In these fractions, STEP $_{65}$ clearly exists as a doublet with a sharp polypeptide band of $64 \mathrm{kDa}$ and broader band of ap- proximately $66 \mathrm{kDa}$. The two bands forming this doublet coenrich in particulate fractions with the upper band appearing more intense in P3 and LP2 fractions. The molecular weight range and upward smearing of the $66 \mathrm{kDa}$ band is suggestive of posttranslational modification by either phosphorylation or glycosylation. Although enrichment of $\mathrm{STEP}_{65}$ occurred in fractions containing membranes of small organelles and synaptic vesicles, additional Western blots showed no association of STEP $_{65}$ with 


\begin{tabular}{|c|c|c|}
\hline Brain region & $\begin{array}{l}\text { STEP-ir } \\
\text { cell bodies }\end{array}$ & $\begin{array}{l}\text { STEP-ir } \\
\text { neuropil }\end{array}$ \\
\hline Amygdala & ++ & - \\
\hline Anterior pretectal nucleus & + & - \\
\hline arcuate nucleus & ++ & - \\
\hline CA1, hippocampus & + & - \\
\hline CA2, hippocampus & ++++ & - \\
\hline Caudate-putamen & ++++ & ++++ \\
\hline Central gray & + & - \\
\hline Cortex layers II + III, V and VI & +++ & + \\
\hline Dentate gyrus & ++ & - \\
\hline Dorsal cochlear nucleus & ++ & - \\
\hline Dorsal fornix & - & +++ \\
\hline Dorsomedial hypothalamic nucleus & +++ & - \\
\hline Entopeduncular nucleus & - & ++ \\
\hline Facial nucleus & ++ & - \\
\hline Globus pallidus & - & +++ \\
\hline Hypoglossal nucleus & + & - \\
\hline Indusium griseum & ++++ & +++ \\
\hline Inferior olive & - & + \\
\hline Internal capsule & - & ++ \\
\hline Interpeduncular nucleus & ++ & - \\
\hline Islands of Calleja & ++++ & ++++ \\
\hline Lateral posterior thalamic nucleus & + & - \\
\hline Lateral septal nucleus & ++++ & - \\
\hline Medial geniculate & +++ & - \\
\hline Medial preoptic area & ++ & - \\
\hline Medullary reticular field & + & - \\
\hline Nucleus accumbens & ++++ & ++++ \\
\hline Nucleus optic tract & ++ & - \\
\hline Oculomotor nucleus & + & + \\
\hline Olfactory tubercle & ++ & ++++ \\
\hline Pontine nucleus & - & +++ \\
\hline Red nucleus & ++ & - \\
\hline Reticular thalamic nucleus & ++ & ++ \\
\hline Septohippocampal nucleus & ++++ & ++++ \\
\hline Spinal trigeminal nucleus & ++ & - \\
\hline Substantia nigra & - & ++++ \\
\hline Superior colliculus & + & - \\
\hline Supraoptic nucleus & +++ & +++ \\
\hline Tanycytes & - & ++ \\
\hline Tenia tecta & ++ & - \\
\hline Transverse fibers pons & - & +++ \\
\hline
\end{tabular}

Relative intensity of STEP immunoreactivity in cell bodies and neuropil in various structures in the adult rat brain. ++++ , strong staining; ++ , moderate staining: - no staining.

purified synaptic vesicle membranes. Taken together, these data suggest that STEP $_{65}$ is associated with membranes of small organelles present both in neuronal soma and synaptosomes (i.e., endoplasmic reticulum). Preliminary studies also suggest that the association of STEP $_{65}$ with membranes is not disrupted by high ionic strength, and biochemical studies are now underway to identify the precise subcellular location of $\mathrm{STEP}_{65}$ and the nature of its association with the membrane. Whether STEP $_{65}$ is a phosphatase has yet to be determined and clarification will require purifying and sequencing of the $65 \mathrm{kDa}$ protein.

The regional comparisons of different STEP immunoreactive polypeptides showed highest levels of all STEP immunoreactive bands in caudate-putamen. A moderate enrichment of $\mathrm{STEP}_{46}$ was found in frontal cortex relative to other cortical regions. STEP $_{65}$ was found to be enriched in several cortical areas in addition to the caudate-putamen, but was not detected in substantia nigra. At the present time, we are unable to distinguish between the possibilities that STEP $_{65}$ is produced selectively by cortical neurons and then transported within their axons to the striatum, or produced within both cortical and striatal neurons. If striatal projection neurons express all isoforms of STEP, but only $\mathrm{STEP}_{65}$ is not detected in the substantia nigra, it suggests that the lower molecular forms of STEP are transported within striatonigral axons, while $\mathrm{STEP}_{65}$ is not.

Evidence that STEP polypeptides are generated by alternative splicing of a single STEP gene

We hypothesize that the different molecular weight forms of STEP are members of a family of polypeptides generated through alternative splicing of a single STEP gene. The strongest support for this hypothesis has been obtained in studies in which the original full length STEP cDNA clone was used as a probe to screen a mouse eDNA brain library. Over 100 positive clones were obtained after stringent hybridization and several of these have been sequenced. Some of these clones contain sequences which diverge from the original sequence and represent alternatively spliced variants. The novel sequences were determined not to be cloning artifacts by locating the identical sequences within a mouse genomic clone for STEP (Lombroso et al., 1994). All of the clones isolated to date maintain the 18 amino acid sequence used to generate both the monoclonal used in the present study and the polyclonal antibody used in our previous study (Lombroso et al., 1993). Several of the alternatively spliced clones encode for proteins with predicted molecular weights greater than the original STEP sequence of $42 \mathrm{kDa}$ and two clones encode for proteins with a predicted molecular weight of approximately $65 \mathrm{kDa}$. We are investigating whether these candidate cDNA clones encode for $\mathrm{STEP}_{65}$.

Additional support for our hypothesis was obtained in previous Northern blot analyses of STEP mRNA in rat brain. Two distinct mRNA transcripts were expressed in different brain regions: a $3 \mathrm{~kb}$ transcript was highly enriched within the caudate-putamen and detected in several cortical regions, while an additional, $4.4 \mathrm{~kb}$ mRNA transcript was only detected in cortical structures (Lombroso et al., 1991). Southern blots of genomic DNA using the original full length STEP $\operatorname{cDN} \Lambda$ as a probe, demonstrated the existence of a single gene (Lombroso et al., 1991). These observations taken together suggest that the STEP immunoreactive bands observed in the present study are the products of alternatively spliced variants of a single STEP gene.

There are several other explanations that could account for the data presented in this study and these cannot yet be ruled out. Some of the multiple STEP polypeptides could arise from normal proteolytic cleavage and/or posttranslational modifications of a single STEP polypeptide. These forms might have distinct functional roles within cells. This explanation probably cannot account for all STEP forms because the smallest form, $\mathrm{STEP}_{33}$, is expressed during development several days prior to the appearance of any of the other higher molecular weight bands (Boulanger et al., 1993).

An alternative explanation is that the multiple STEP immunoreactive bands correspond to unrelated polypeptides with a shared epitope. This explanation seems unlikely for several rea- 

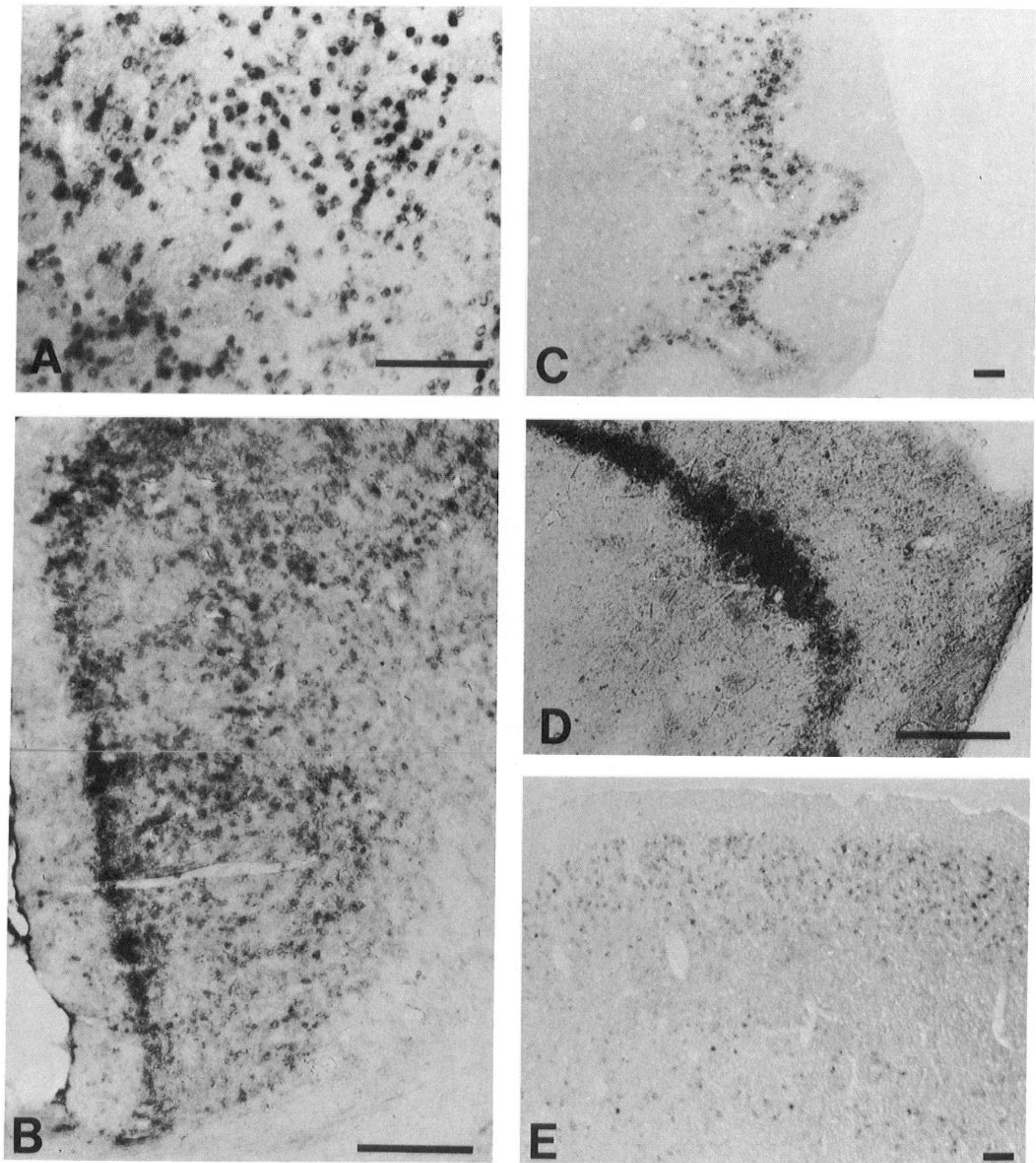

Figure 7. Photomicrographs of STEP mRNA localized by in situ hybridization with digoxigenin-labeled STEP cRNA probes. $A$, Caudate-putamen; $B$, retrosplenial cortex; $C$, piriform cortex and olfactory tubercle; $D$, pyramidal cell layer of hippocampus; $E$, occipital cortex. Scale bar, $100 \mu m$.

sons. First, all of the $22 \mathrm{mAbs}$ generated against STEP in the present study labeled the same set of STEP polypeptide bands. Second, immunocytochemical staining patterns produced by these monoclonal antibodies were identical to the patterns produced by a previous polyclonal antiserum generated against the identical 18 amino acid peptide from STEP (Lombroso et al.,
1993). Third, with either the polyclonal or monoclonal antibodies, immunocytochemical staining was abolished by preabsorption of antibodies with either the peptide or STEP fusion protein (Lombroso et al., 1993). More definitive proof that the different bands are related will entail purification and sequencing of the individual bands. 
The relationship between STEP, dopamine innervated brain regions, and subclasses of dopamine receptors

STEP immunoreactivity was found previously to colocalize with DARPP-32, a dopamine- and cAMP-regulated phosphoprotein, in medium-sized spiny neurons of the caudate-putamen (Lombroso et al., 1993). This population of striatal neurons also contains additional members of the set of cAMP-regulated phosphoproteins besides DARPP-32 (Ouimet et al., 1984) including: ARPP-21 (Ouimet et al., 1989), ARPP-19, and ARPP-16 (Girault et al., 1990). In addition, these neurons are known to utilize GABA, enkephalin, dynorphin, and substance $P$ as transmitters (reviewed in Graybiel, 1990) and receive glutamatergic inputs from the cortex and dopaminergic inputs from the substantia nigra. The distribution of STEP immunoreactive polypeptides and mRNA also corrclates well with the pattern of expression of mRNA for the $D_{1 A}$ subtype of dopamine receptor which is expressed at highest levels in the caudate-putamen, the nucleus accumbens, olfactory tubercle, and to a lesser extent, in the cerebral cortex, hippocampus, hypothalamus, and thalamus (Fremeau et al., 1991).

The colocalization of DARPP-32 and STEP within striatal neurons raises the question of whether there is some level of cross-talk between these two proteins. However, DARPP-32 is a potent serine and threonine phosphatase inhibitor and does not inhibit the phosphatase activity of STEP (Lombroso and Hemmings, unpublished observations). In addition, DARPP-32 is not phosphorylated on tyrosine residues and thus does not serve as a substrate for STEP. These observations suggest that DARPP32 and STEP do not interact directly. The possibility exists that their paths may converge on an unidentified substrate molecule which requires both serine/threonine and tyrosine phosphorylation.

In conclusion, our results indicate that there are multiple forms of STEP in the adult rat brain which show differential enrichment in brain regions implicated in aspects of cognitive, affective, and motor behaviors. The neural circuits enriched in STEP isoforms and their corresponding mRNAs constitute a functional pathway extending through frontal and limbic cortex, striatum, thalamus, and hypothalamus. It is likely that some, if not all, of the STEP isoforms are generated through alternative splicing of a single STEP gene and that each has unique intracellular targets and functions.

\section{References}

Boulanger LM, Apicelli G, Kim P, Matthews G, Lombroso PJ, Naegele JR (1993) A tyrosine phosphatase expressed in developing and adult rat brain. Soc Neurosci Abstr 19:1110

Charbonneau H, Tonks NK (1992) 1002 protein phosphatases? Annu Rev Cell Biol 8:463-493.

Charbonncau H, Tonks NK, Dumar S, Diltz C, Harrylock M, Cool DE, Krebs EG, Fischer EJ, Walsh KA (1989) Human placenta proteintyrosine-phosphatase: amino acid sequence and relationship to a family of receptor-like proteins. Proc Natl Acad Sci USA 8:5252-5256.

Cool DE, Tonks NK, Charbonneau H, Walsh KA, Fischer EH, Krebs EG (1989) cDNA isolated from a human T-cell library encodes a member of the protein-tyrosine-phosphatase family. Proc Natl Acad Sci USA 86:5257-5261.

Cool DE, Tonks NK, Charbonneau H, Fischer EH, Krebs EG (1990) Expression of a human T-cell protein tyrosine phosphatase in baby hamster kidney cells. Proc Natl Acad Sci USA 87:7280-7284.

During MJ, Acworth IN, Wurtman RI (1989) Dopamine release in rat caudate-putamen: physiological coupling to tyrosine supply. J Neurochem 52:1449-1454.

During MJ, Freese A, Deutch $\Lambda Y$, Kibat PG, Sabel B $\Lambda$, Langer R, Roth RH (1992) Biochemical and behavioral recovery in a rodent model of Parkinson's disease following stereotaxic implants of dopaminecontaining liposomes. Exp Neurol 115:193-199.

Feng FS, Hui CC, Pawson T (1993) SH2-containing phosphotyrosine phosphatase as a target of protein tyrosine kinases. Science 259: $1607-1610$.

Fischer EH, Charbonneau H, Tonks NK (1991) Protein tyrosine phosphatases: a diverse family of intracellular and transmembrane enzymes. Science 253:401-406.

Frangioni JV, Beahm PH, Shifrin V, Jost CA, Neel BG (1992) The nontransmembrane tyrosine phosphatase PTP-1B localizes to the endoplasmic reticulum via its 35 amino acid C-terminal sequence. Cell 68:545-560.

Fremeau RT Jr, Duncan GE, Fornaretto MG, Dearry A, Gingrich JA, Breese GR, Caron MG (1991) Localization of D1 dopamine receptor mRNA in brain supports a role in cognitive, affective and neuroendocrine aspects of dopaminergic transmission. Proc Natl Acad Sci USA 88:3772-3776.

Girault JA, Horiuchi A, Gustafson EL, Rosen N, Greengard P (1990) Differential expression of ARPP-16 and ARPP-19, two highly related cAMP-regulated phosphoproteins, one of which is specifically associated with dopamine-innervated brain regions. J Neurosci 10:11241133.

Graybiel AM (1990) Neurotransmitters and neuromodulators in the basal ganglia. Trends Neurosci 13:244-254.

Greengard P (1987) Neuronal phosphoproteins. Mol Neurobiol 1:81119.

Gu M, York JD, Warshawsky I, Majerus P (1991) Identification, cloning and expression of a cytosolic megakaryocyte protein-tyrosinephosphatase with sequence homology to cytoskeletal protein 4.1. Proc Natl Acad Sci USA 88:5867-5871.

Guan K, Haun RS, Watson SJ, Geahlen RL, Dixon JE (1990) Cloning and expression of a protein tyrosine phosphatase. Proc Natl Acad Sci USA 87:1501-1505.

Harihan IK, Chuang PT, Rubin GM (1991) Cloning and characterization of a receptor-class phosphotyrosine phosphatase gene expressed on central nervous system axons in Drosophila melanogaster. Proc Natl Acad Sci USA 88:11266-11270.

Hefti F, Melamed E, Sahakian BJ, Wurtman RJ (1980) Circling behavior in rats with partial, unilateral nigral lesions: effects of amphetamine, apomorphine, and DOPA. Pharmacol Biochem Behav 12: $185-188$.

Hemmings HC Jr, Nairn AC, Aswad DW, Greengard P (1984) DARPP32 , a dopamine- and adenosine $3^{\prime}: 5^{\prime}$ monophosphate regulated phosphoprotein entiched in dopamine-innervated brain regions. II. Purification and characterization of the phosphoprotein from bovine caudate nucleus. J Neurosci 4:99-110.

Hicks D, Molday RS (1984) Analysis of cell labelling for scanning and transmission electron microscopy. In: Science of biological specimen preparation (Johari O, ed), pp 2203-2219. Chicago: SEM.

Huganir RL, Greengard P (1990) Regulation of neurotransmitter receptor desensitization by protein phosphorylation. Neuron 5:555567.

Hunter T, Cooper JA (1985) Protein tyrosine kinases. Annu Rev Biochem 54:897-930.

Huttner WB, Schiebler W, Greengard P, DeCamilli P (1983) Synapsin I (protein I), a nerve terminal specific phosphoprotein. III. Its association with synaptic vesicles studied in a highly purified synaptic vesicle preparation. J Cell Biol 96:1374-1388.

Jirik FR, Janzen NM, Melhado IG, Harder KW (1990) Cloning and chromosomal assignment of a widely expressed human receptor-like protein-tyrosine phosphatase. FEBS Lett 273:239-242.

Kaplan R, Morse B, Huebner K, Croce C, Howe R, Ravera M, Ricca G, Jaye M, Schlessinger J (1990) Cloning of three human tyrosine phosphatases reveals a multigene family of receptor-linked proteintyrosine-phosphatases cxpressed in brain. Proc Natl Acad Sci USA 87:7000-7004.

Klein R, Parada LF, Coulier F, Barbacid M (1989) trkB, a novel tyrosine protein kinase receptor expressed during mouse neural development. EMBO J 8:3701-3709.

Klein R, Martin-Zanca D, Barbacid M, Parada LF (1990) Expression of the tyrosine kinase receptor gene trkB is confined to the murine embryonic and adult nervous system. Development 109:845-850.

Kohler G, Milstein C (1975) Continuous cultures of fused cells secreting antibody of predefined specificity. Nature 256:495-497. 
Laemmli UK (1970) Cleavage of structural proteins during the preassembly of the head of bacteriophage T4. Nature 227:680-685.

Lai C, Lemke G (1991) An extended family of protein-tyrosine kinase genes differentially expressed in the vertebrate nervous system. Neuron 6:691-704.

Levy J, Canoll P, Silvennoinen O, Barnia G, Morse B, Honegger A, Huang J, Cannizzaro OL, Park S, Druck T, Huebner K, Sap J, Ehrlich M, Musacchio J, Schlessinger J (1993) The cloning of a receptortype protein tyrosine phosphatase expressed in the central nervous system. J Biol Chem 268:10573-10581.

Lombroso PJ, Murdoch G, Lerner M (1991) Molecular characterization of a protein-tyrosine-phosphatase enriched in caudate-putamen. Proc Natl Acad Sci USA 88:7242-7246.

Lombroso PJ, Naegele JR, Sharma E, Lerner M (1993) A brain enriched protein tyrosine phosphatase is present in dopaminoceptive neurons. J Neurosci 13:3064-3074.

Lombroso PJ, Zhao F, Sharma E, Bult A (1994) A family of alternatively spliced protein tyrosine phosphatases enriched in the CNS. Soc Neurosci Abstr 20:219.

Martin-Zanca D, Barbacid M, Parada LF (1990) Expression of the trk proto-oncogene is restricted to the sensory, cranial and spinal ganglia of neural crest origin in mouse development. Genes Dev 4:683-694.

Matthews RJ, Cahir ED, Thomas ML (1990) Identification of an additional member of the protein-tyrosine-phosphatase family: evidence for alternative splicing in the tyrosine phosphatase domain. Proc Natl Acad Sci USA 87:4444-4448.

McPherson PS, Czernik AJ, Chilcote TJ, Onofri F, Benfenati F, Greengard P, Schlessinger J, De Camilli P (in press). Interaction of GRB2 via its $\mathrm{SH} 3$ domains with synaptic proteins including synapsin I. Proc Natl Acad Sci USA.

Mei L, Huganir RL (1991) Purification and characterization of a protein tyrosine phosphatase which dephosphorylates the nicotinic acetylcholine receptor. J Biol Chem 266:16063-16072.

Ouimet CC, Miller PE, Hemmings HC Jr, Wallas SI, Greengard P (1984) DARPP-32, a dopamine- and adenosine $3^{\prime}: 5^{\prime}$-monophosphate-regulated phosphoprotein enriched in dopamine-innervated brain regions. II. Immunocytochemical localization. J Neurosci 4:111-124.

Ouimet CC, Hemmings HC Jr, Greengard P (1989) ARPP-21, a cyclic AMP-regulated phosphoprotein enriched in dopamine-innervated brain regions. II. Immunocytochemical localization in rat brain. $\mathrm{J}$ Neurosci 9:865-875.

Perese DA, Ulman J, Viola J, Ewing SE, Bankiewicz KS (1989) A 6-hydroxydopamine-induced selective parkinsonian rat model. Brain Res 494:285-293.

Sahin M, Hockfield S (1993) Protein tyrosine phosphatases expressed in the developing rat brain. J Neuroscience 13:4968-4978.

Sap J, D'Eustachio P, Givol D, Schlessinger J (1990) Cloning and expression of a widely expressed receptor tyrosine phosphatase. Proc Natl Acad Sci USA 87:6112-6116.

Shen S, Bastien L, Posner B, Chretien P (1991) A protein-tyrosine phosphatase with sequence similarity to the SH2 domain of the protein-tyrosine kinases. Nature 352:736-739.

Streuli M, Krueger NX, Hall LR, Schlossman SF, Saito H (1988) A new member of the immunoglobulin supcrfamily that has a cytoplasmic region homologous to the leukocyte common antigen. J Exp Med 168:1553-1562.

Streuli M, Krueger NX, Tsai AY, Saito H (1989) A family of receptorlinked protein tyrosine phosphatases in humans and Drosophila. Proc Natl Acad Sci USA 86:8698-8702.

Tian S, Tsoulfas P, Zinn K (1991) Three receptor-linked protein-tyrosine phosphatases are selectively expressed on central nervous system axons in the Drosophila embryo. Cell 67:675-685.

Towbin H, Staehelin T, Gordon J (1979) Electrophoretic transfer of proteins from polyacrylamide gels to nitrocellulose sheets: procedure and some applications. Proc Natl Acad Sci USA 76:4350-4354.

Ullrich A, Schlessinger J (1990) Signal transduction by receptors with tyrosine kinase activity. Cell $61: 203-212$

Vogel W, Lammers R, Huang J, Ullrich A (1993) Activation of a phosphotyrosine phosphatase by tyrosine phosphorylation. Science 259 : 1611-1614.

Wahle P, Beckh S (1992) A method of in situ hybridization combined with immunocytochemistry, histochemistry and tract tracing to characterize the mRNA expressing cell types in heterogenious neuronal populations. J Neurosci Methods 41:153-166.

Walaas SI, Greengard P (1984a) A dopamine- and cyclic AMP-regulated phosphoprotein enriched in dopamine-innervated brain regions. Nature 301:69-71.

Walaas SI, Greengard P (1984b) A dopamine- and adenosine 3':5' monophosphate-regulated phosphoprotein enriched in dopamine-innervated brain regions. I. Regional and cellular distribution in the rat brain. J Neurosci 4:84-98.

Walaas SI, Greengard P (1991) Protein phosphorylation and neuronal function. Pharmacol Rev 43:299-349.

Walton KM, Martell KJ, Kwak SP, Dixon JE, Largent BL (1993) A novel receptor-type protein tyrosine phosphatase is expressed during neurogenesis in the olfactory neuroepithelium. Neuron 11:387-400.

Yang Q, Tonks N (1991) Isolation of a cDNA clone encoding a human protein-tyrosine phosphatase with homology to the cytoskeletal-associated proteins band 4.1, ezrin and talin. Proc Natl Acad Sci USA 88:5949-5953.

Yang X, Seow KT, Bahri SM, Oon SH, Chia W (1991) Two Drosophila receptor-like tyrosine phosphatase genes are expressed in a subset of developing axons and pioneer neurons in the embryonic CNS. Cell 67:661-673. 